\title{
JEJUNAL MICROBIAL FLORA OF SOUTHERN INDIAN INFANTS IN HEALTH AND WITH ACUTE GASTROENTERITIS
}

\author{
M. J. Albert, P. Bhat, D. Rajan, P. P. Maiya, S. M. Pereira, \\ M. MATHAN AND S. J. BAKER* \\ Wellcome Research Unit, Departments of Child Health and Pathology, \\ Christian Medical College and Hospital, Vellore 632 004, Tamil Nadu, India
}

ACUTE gastroenteritis in infancy is an important cause of morbidity and mortality in many parts of the world (Gordon, 1971). Recent studies from this hospital (Maiya et al., 1977) have shown that in southern India, it is most frequently due to infection with a variety of bacterial pathogens, or to infection with rotavirus, but in some cases the aetiology remains obscure. In order to obtain more information on aetiology and pathogenesis, the bacterial flora in the lumen of the jejunum of infants with acute gastroenteritis was studied and compared with that of control subjects.

\section{MATERIALS AND METHODS}

Subjects. Twenty-eight infants, aged 2-12 months, who were admitted to hospital with acute diarrhoea of 1-3 days' duration were studied. The infants belonged to parents of low socio-economic status. Ten infants of similar age and socio-economic status without any evidence of gastrointestinal disease were studied as controls. Consent of the parents was obtained for the participation of their children in the study. All the children were receiving breast-milk feedings supplemented with cows' milk. None of the patients or the controls had received any antimicrobial therapy before the investigation.

Specimens. Specimens of jejunal juice were collected by introducing a sterile radioopaque polyvinyl tube, with the aid of a fluoroscope, an image intensifier and a television chain. When the tube reached the upper jejunum just below the duodenojejunal flexure, intestinal juice was aspirated. The first few millilitres of the aspirate were discarded. The next 2-5 ml of juice were placed in a sterile container and processed immediately.

Specimens were obtained as soon as possible after the patients were admitted to hospital. In severely dehydrated patients, the specimens of jejunal juice were obtained after rehydration, always within $24-48 \mathrm{~h}$ of admission. The specimens from patients were obtained when either nothing or merely sterile electrolyte solution had been given by mouth. Specimens from the controls were obtained at least $6 \mathrm{~h}$ after the last feed.

A fresh stool specimen was also collected in a sterile container as nearly as possible to the time of intubation. This was also processed immediately.

Microbiological methods. The jejunal juice was diluted with sterile saline to produce dilutions ranging from $10^{1}$ to $10^{8}$. The faecal sample was suspended in sterile saline to give a concentration of $0.1 \mathrm{~g}$ per $\mathrm{ml}$ and this material was similarly diluted over the range $10^{1}$ to $10^{8} ; 0 \cdot 1-\mathrm{ml}$ portions of the dilutions were cultured on various media. The details of the media, the methods of incubation and the various groups of organisms identified are

Received 25 Oct. 1977; revised version accepted 28 Feb. 1978.

* Present address: Department of Medicine, St Boniface Hospital, Winnipeg, Manitoba, Canada R2H 2 A6.

J. MED. MICROBIOL.-VOL. 11 (1978) 
reported elsewhere (Bhat et al., 1972). Bacterial counts are expressed as the logarithm to the base of 10. The sera used for detection of enteropathogenic Escherichia coli (EEC) covered the following serotypes-0111:B4, 055:B5, 026:B6, 086:B7, 0127:B8, 0124:B17, 0125:B15, 0126:B16, 0128:B12 and 0119:B14. Stools were examined for rotavirus particles by the method of Flewett, Bryden and Davies (1974).

\section{RESULTS}

The bacteriological findings in the jejunal samples are shown in table I. Samples from the control infants had total viable bacterial counts that ranged from 1.8 to 5.7 (expressed as the $\log _{10}$ of the count per $\mathrm{ml}$ of juice). In the samples from infants with diarrhoea, the total counts ranged from 2 to $8.6 \mathrm{log}$ (expressed as the $\log _{10}$ of the count per $\mathrm{ml}$ of original material). Enterobacteria and lactobacilli were present in these samples in significantly greater numbers than in samples from the controls $(P<0.05)$. Enterococci and bacteroides organisms were present respectively in five and six of the specimens from patients, but were not found in specimens from the controls. The total Gram-negative aerobic rods in the jejunal juice of controls and patients is shown diagramatically in the figure. A detailed analysis of the Gram-negative aerobic rods found in the jejunal samples, and the presumed pathogens grown

TABLE I

Aerobic and anaerobic microflora cultured from jejunal aspirates of 10 control subjects and 28 patients with diarrhoea

\begin{tabular}{|c|c|c|c|c|c|c|}
\hline Organisms & $\begin{array}{l}\text { Numbers } \\
\text { of } \\
\text { control } \\
\text { subjects } \\
\text { positive }\end{array}$ & $\begin{array}{l}\text { Mean } \\
\text { counts* } \\
\text { in } \\
\text { control } \\
\text { subjects }\end{array}$ & $\begin{array}{l}\text { Ranges of } \\
\text { counts* } \\
\text { in } \\
\text { control } \\
\text { subjects }\end{array}$ & $\begin{array}{l}\text { Numbers } \\
\text { of } \\
\text { patients } \\
\text { positive }\end{array}$ & $\begin{array}{l}\text { Mean } \\
\text { counts* } \\
\text { in } \\
\text { patients }\end{array}$ & $\begin{array}{l}\text { Ranges } \\
\text { of } \\
\text { counts* } \\
\text { in } \\
\text { patients }\end{array}$ \\
\hline $\begin{array}{l}\text { Enterobacteria } \dagger \\
\text { Pseudomonads and other } \\
\text { non-fermenting Gram- } \\
\text { negative rods }\end{array}$ & $\begin{array}{l}4 \\
4\end{array}$ & $\begin{array}{l}2.7 \\
3.0\end{array}$ & $\begin{array}{l}2 \cdot 0-3 \cdot 7 \\
2 \cdot 0-4 \cdot 3\end{array}$ & $\begin{array}{r}16 \\
9\end{array}$ & $\begin{array}{l}5 \cdot 3 \\
4 \cdot 3\end{array}$ & $\begin{array}{l}3 \cdot 0-8 \cdot 4 \\
2 \cdot 3-7 \cdot 3\end{array}$ \\
\hline $\begin{array}{l}\text { Neisseriae } \\
\text { Staphylococci including } \\
\text { micrococci }\end{array}$ & $\begin{array}{l}3 \\
2\end{array}$ & $\begin{array}{l}3 \cdot 3 \\
4 \cdot 1\end{array}$ & $\begin{array}{l}2 \cdot 6-4 \cdot 5 \\
3 \cdot 3-4 \cdot 8\end{array}$ & $\begin{array}{l}4 \\
3\end{array}$ & $\begin{array}{l}4 \cdot 0 \\
3 \cdot 5\end{array}$ & $\begin{array}{l}2 \cdot 1-5 \cdot 2 \\
2 \cdot 6-4 \cdot 6\end{array}$ \\
\hline $\begin{array}{l}\text { Enterococci } \\
\text { Streptococci } \\
\text { Lactobacilli } \uparrow \\
\text { Total aerobes }\end{array}$ & $\begin{array}{r}0 \\
9 \\
5 \\
10\end{array}$ & $\begin{array}{l}4 \cdot 5 \\
2 \cdot 6 \\
4 \cdot 6\end{array}$ & $\begin{array}{l}2 \cdot 3-5 \cdot 7 \\
1 \cdot 5-4 \cdot 2 \\
1 \cdot 9-5 \cdot 7\end{array}$ & $\begin{array}{r}5 \\
22 \\
12 \\
27\end{array}$ & $\begin{array}{l}4 \cdot 4 \\
4 \cdot 9 \\
4 \cdot 3 \\
5 \cdot 3\end{array}$ & $\begin{array}{l}2 \cdot 8-6 \cdot 9 \\
2 \cdot 7-7 \cdot 6 \\
1 \cdot 7-6 \cdot 4 \\
2 \cdot 0-8 \cdot 6\end{array}$ \\
\hline $\begin{array}{l}\text { Yeasts and yeast-like } \\
\text { organisms }\end{array}$ & 4 & $2 \cdot 1$ & $1.0-3 \cdot 4$ & 16 & $3 \cdot 4$ & $2 \cdot 0-5 \cdot 9$ \\
\hline $\begin{array}{l}\text { Bifidobacteria } \\
\text { Bacteroides } \\
\text { Fusobacteria } \\
\text { Veillonellae } \\
\text { Anaerobic streptococci } \\
\text { Total anaerobes }\end{array}$ & $\begin{array}{l}5 \\
0 \\
4 \\
5 \\
4 \\
8\end{array}$ & $\begin{array}{l}2 \cdot 8 \\
2.0 \\
3 \cdot 7 \\
4 \cdot 6 \\
3.9\end{array}$ & $\begin{array}{l}1 \cdot 0-3 \cdot 3 \\
2 \cdot 7-4 \cdot 6 \\
3 \cdot 8-5 \cdot 4 \\
2 \cdot 0-5 \cdot 5\end{array}$ & $\begin{array}{r}6 \\
6 \\
2 \\
12 \\
17 \\
23\end{array}$ & $\begin{array}{l}4 \cdot 2 \\
4 \cdot 1 \\
1 \cdot 2 \\
3 \cdot 5 \\
5 \cdot 1 \\
5 \cdot 0\end{array}$ & $\begin{array}{l}1 \cdot 8-6 \cdot 5 \\
2 \cdot 3-7 \cdot 6 \\
1 \cdot 0-1 \cdot 3 \\
1 \cdot 0-5 \cdot 0 \\
2 \cdot 7-7 \cdot 2 \\
1 \cdot 8-7 \cdot 6\end{array}$ \\
\hline Total bacteria & 10 & $4 \cdot 7$ & $1.9-5 \cdot 7$ & 27 & $5 \cdot 6$ & $2 \cdot 0-8 \cdot 6$ \\
\hline
\end{tabular}

* Values are expressed as $\log _{10}$ bacterial count per ml of fluid.

$\dagger$ The differences between controls and patients are significant at the $5 \%$ level. 


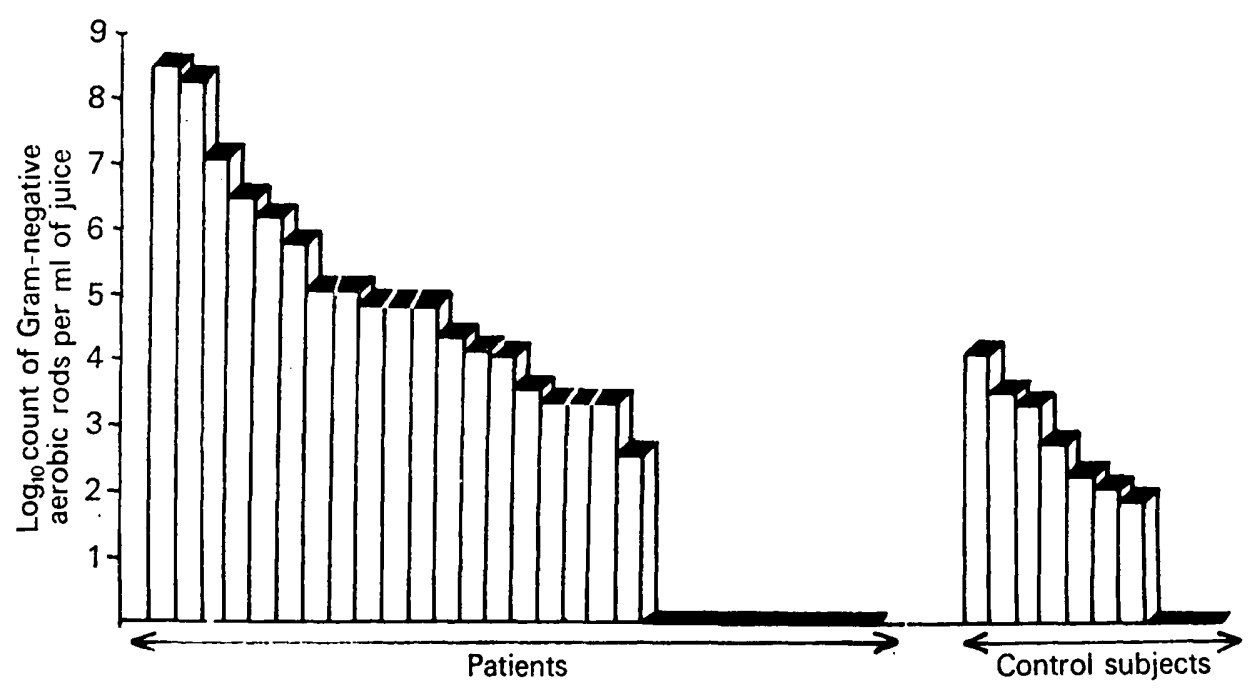

FIGURE.-The total number of Gram-negative aerobic rods in the jejunal juice of infants with gastroenteritis and control infants.

from the stools, are shown in table II. In eight patients (nos. 1-8) the same presumed bacterial pathogen was recovered from both the jejunal juice and the stool. Three patients (nos. 9-11) had presumed pathogens in the stool, but these organisms were not found in the jejunal juice, even though it contained other Gram-negative aerobic rods. In seven patients (nos. 12-18) Gramnegative aerobic rods were present in the jejunum, but no presumed pathogens were isolated from the jejunum or stools. In four patients (nos. 19-22) no Gram-negative aerobic rods were isolated from the jejunum, but in three a pathogenic $E$. coli was isolated from the stool. In none of these 22 infants was rotavirus detected.

In five of six patients (nos. 23-28) in whom rotavirus was present in the stools, no Gram-negative aerobic rods were found in the jejunal juice, but in one (no. 28) pseudomonads were present with a low viable count of $2.7\left(\log _{10}\right.$ per $\mathrm{ml}$ ). In one of these patients (no. 27) EEC 086:B7 was present in the faeces with a count of $7 \cdot 4\left(\log _{10}\right.$ per $\left.\mathrm{ml}\right)$.

\section{DisCUSSION}

The bacteria found in the jejunal juice of the control subjects in this study are comparable with those found by Challacombe, Richardson and Anderson (1974a) in normal English children who had an " oral "type of flora, and in the Australian children studied by Bishop, Barnes and Townley (1974a), who also had a mainly " oral " type of flora although a few children harboured coliforms. However, in these earlier studies, bacteria were present in only half of the subjects, half the samples being sterile, whereas in the present study all the control subjects had bacteria in their jejunal juice. The greater colonisation of the jejunum in south Indian infants is in conformity with studies in adults published previously (Bhat et al., 1972). 


\section{TABLE II}

Gram-negative aerobic bacilli isolated from the jejunum or faeces of 22 patients with gastroenteritis in whom rotavirus was not found

\begin{tabular}{|c|c|c|c|c|}
\hline $\begin{array}{l}\text { Patient } \\
\text { no. }\end{array}$ & $\underset{\text { jejunum }}{\text { Organisms in }}$ & $\begin{array}{l}\text { Count }\left(\log _{10}\right. \\
\text { per ml) in } \\
\text { jejunum }\end{array}$ & $\begin{array}{l}\text { Presumed } \\
\text { pathogens } \\
\text { in faeces }\end{array}$ & $\begin{array}{l}\text { Count }\left(\log _{10}\right. \\
\text { per ml) of } \\
\text { presumed } \\
\text { pathogens in } \\
\text { faeces }\end{array}$ \\
\hline $\begin{array}{l}1 \\
2\end{array}$ & $\begin{array}{l}\text { EEC 0125:B15 } \\
\text { EEC 0125:B15 } \\
\text { EEC 0111:B4 } \\
E . \text { coli }\end{array}$ & $\begin{array}{l}8.4 \\
5.0 \\
4.5 \\
4.4\end{array}$ & $\begin{array}{l}\text { EEC 0125:B15 } \\
\text { EEC 0125:B15 } \\
\text { EEC 0111:B4 }\end{array}$ & $\begin{array}{r}10.1 \\
7.9 \\
9.0\end{array}$ \\
\hline 3 & $\begin{array}{l}\text { EEC 026:B6 } \\
\text { E. coli }\end{array}$ & $\begin{array}{l}4.4 \\
5.2 \\
4.2\end{array}$ & EEC 026:B6 & $7 \cdot 4$ \\
\hline 4 & $\begin{array}{l}\text { EEC 0119:B14 } \\
\text { E. coli } \\
\text { Klebsiella sp. }\end{array}$ & $\begin{array}{l}4.2 \\
4.2 \\
4.8\end{array}$ & $\begin{array}{l}\text { EEC 0119:B14 } \\
\text { EEC 0111:B4 }\end{array}$ & $\begin{array}{l}8.8 \\
7.9\end{array}$ \\
\hline 5 & $\begin{array}{l}\text { EEC 0128:B12 } \\
\text { Pseudomonas sp. }\end{array}$ & $\begin{array}{l}4.0 \\
8.6 \\
6.0\end{array}$ & EEC 0128:B12 & $9 \cdot 4$ \\
\hline 6 & $\begin{array}{l}\text { Vibrio eltor } \\
\text { Ogawa }\end{array}$ & $6 \cdot 3$ & $\begin{array}{l}\text { Vibrio eltor } \\
\text { Ogawa }\end{array}$ & $5 \cdot 0$ \\
\hline $\begin{array}{l}7 \\
8 \\
9\end{array}$ & $\begin{array}{l}\text { Klebsiella sp.* } \\
\text { Pseudomonas sp.* } \\
\text { E. coli }\end{array}$ & $\begin{array}{l}3 \cdot 5 \\
7 \cdot 2 \\
4 \cdot 5\end{array}$ & $\begin{array}{l}\text { Klebsiella sp. } \\
\text { Pseudomonas sp. } \\
\text { Salmonella sp. } \\
\text { (group B) }\end{array}$ & $\begin{array}{l}6 \cdot 0 \\
8 \cdot 3 \\
L\end{array}$ \\
\hline 10 & E. coli & 3.0 & $\begin{array}{l}\text { Shigella } \\
\text { sonnei }\end{array}$ & $\mathbf{L}$ \\
\hline $\begin{array}{l}11 \\
12 \\
13 \\
14\end{array}$ & $\begin{array}{l}\text { Pseudomonas sp. } \\
\text { Klebsiella sp. } \\
\text { E. coli } \\
\text { E. coli } \\
\text { E. coli } \\
\text { Klebssiella sn }\end{array}$ & $\begin{array}{l}4 \cdot 3 \\
4 \cdot 6 \\
5 \cdot 0 \\
6 \cdot 6 \\
3 \cdot 2 \\
4 \cdot 1\end{array}$ & $\begin{array}{l}\text { EEC } 0125: \mathrm{B} 15 \\
\text { None isolated } \\
\text { None isolated } \\
\text { None isolated }\end{array}$ & $\begin{array}{l}6 \cdot 6 \\
\cdots \\
\cdots \\
\cdots\end{array}$ \\
\hline 15 & E. coli & $\begin{array}{l}3.4 \\
2.6\end{array}$ & None isolated & $\cdots$ \\
\hline 16 & $\begin{array}{l}\text { Klebsiella sp. } \\
\text { E. coli } \\
\text { NFR }\end{array}$ & $\begin{array}{l}5.0 \\
5.8 \\
4.7\end{array}$ & $\begin{array}{l}\text { None isolated } \\
\text { None isolated }\end{array}$ & $\begin{array}{l}\cdots \\
\cdots \\
\cdots\end{array}$ \\
\hline 17 & Pseudomonas sp. & 3.5 & None isolated & $\cdots$ \\
\hline 18 & NFR & $3 \cdot 6$ & None isolated & $\ldots$ \\
\hline 19 & None isolated & $\ldots$ & None isolated & \\
\hline $\begin{array}{l}20 \\
21\end{array}$ & $\begin{array}{l}\text { None isolated } \\
\text { None isolated }\end{array}$ & $\begin{array}{l}\ldots \\
\ldots\end{array}$ & $\begin{array}{l}\text { EEC 0111:B4 } \\
\text { EEC 026:B6 }\end{array}$ & $\begin{array}{l}7 \cdot 9 \\
9 \cdot 2\end{array}$ \\
\hline 22 & None isolated & $\cdots$ & EEC 0128:B12 & $9 \cdot 3$ \\
\hline
\end{tabular}

* See text for discussion on pathogenicity.

$\mathrm{L}=$ Present in low concentration.

$\mathrm{NFR}=$ Non-fermenting aerobic Gram-negative rod other than Pseudomonas spp.

$\mathrm{EEC}=$ Enteropathogenic $E$. coli.

The only available study of the jejunal flora of infants with acute gastroenteritis is that of Bishop et al. (1974a), who found a " faecal type flora "in the duodenum in one-third of the children and no Gram-negative aerobic rods in the duodenum of the remainder; this last group resembled our patients with rotaviruses. In adults, Koya, Kosakai and Fukasawa (1954) gave EEC by mouth to healthy volunteers and showed that in subjects who developed mild diarrhoea a mixed jejunal microflora occurred, consisting of the EEC strain administered 
as well as other coliforms, while in those who developed severe diarrhoea the strain of EEC that had been administered predominated. Gorbach et al. (1971) also found that patients with a "mixed flora" in the upper small intestine had a relatively mild disease. The present study, however, failed to show a correlation between the severity of diarrhoea as judged by the degree of dehydration, and the relative prevalence of pathogens in the jejunal aspirate.

There is very little information on the distribution of pathogens in the intestine in acute gastroenteritis. Thomson (1955) demonstrated EEC in the upper small intestine of one child with diarrhoea and Challacombe et al. (1974b) recovered the same EEC serotype from the duodenum and rectum of a child with acute diarrhoea. Gorbach et al. $(1970,1971)$ demonstrated Vibrio cholerae in the upper small intestine and stools of children with cholera, and toxigenic $E$. coli in the jejunum and stools of adults with acute undifferentiated diarrhoea.

In the present study, where children had the same pathogens in the stool and jejunal juice (patients 1-6) it may be assumed that these caused the diarrhoea. The jejunal aspirate of two infants (nos. 7 and 8) grew pure cultures of klebsiellae and pseudomonads respectively; since these were the only Gramnegative aerobic rods cultured they were presumed to be responsible for the disease. Apart from $E$. coli, other organisms have also been incriminated as a cause of gastroenteritis and diarrhoea; for example, klebsiellae in infants (Olarte et al., 1961) and in patients with tropical sprue (Klipstein et al., 1973) and pseudomonads in infants (Henderson, Maclaurin and Scott, 1969; Wadstrom et al., 1976; Ferrao and Mavinkurve, 1977). These organisms were present in the jejunum in several of the infants, either alone or with other organisms, and in certain instances may have caused the illness.

When rotaviruses were present they presumably caused the disease (Bishop et al., 1947b; Flewett, Davies, Bryden and Robertson, 1974; Middleton et al., 1974). In one patient, EEC was also present, but as it was not found in the jejunum it was probably coincidental. Only one child with rotavirus had Gram-negative aerobic rods in the jejunal juice. This child is in striking contrast with patients $1-18$ and the findings indicate that the symptoms must have been due to the virus and not to secondary bacterial overgrowth of the upper small intestine.

Three of the four children (patients 19-22) with diarrhoea not associated with rotavirus and without Gram-negative aerobic rods in the jejunum had EEC in their stools; the EEC, however, may not have caused the illness as they were not found in the upper jejunum.

In the three patients (nos. 9-11) in whom a pathogen occurred in the stool but not in the jejunal juice, it is difficult to be sure of the aetiology of the disease. In the two children with Salmonella and Shigella, the absence of the organisms from the jejunal juice was not unexpected, as colonisation occurs in the terminal ileum and colon. Shigellosis usually presents as a dysentery-like illness rather than as gastroenteritis and it seems improbable that it was the cause of the illness. The Salmonella may or may not have been the cause of the diarrhoea. 
In the third child, the absence of EEC in the jejunum makes it likely that the organism was incidental to, rather than the cause of, the illness.

The cause of gastroenteritis in patients 12-18 is undetermined. Typing sera were available for only 10 EEC serotypes. Had more sera been available, other pathogenic serotypes of $E$. coli would probably have been found in both the jejunal samples and the stools of this group. Other $E$. coli serotypes may produce gastroenteritis (Sakazaki, Tamura and Saito, 1967).

The demonstration of enterotoxin has been considered important in deciding whether an organism is pathogenic (Guerrant et al., 1975; Sack et al., 1975). Gross, Scotland and Rowe (1976) found that traditional EEC serotypes, which had caused outbreaks of infantile diarrhoea, were negative for toxin production, and surmised that these serotypes produced diarrhoea by a hitherto unknown mechanism. However, evidence is accumulating that enterotoxin may be produced by serotypes (e.g., 06, 08, 015, 078 etc.) different from the classical ones (Ørskov et al., 1976; Evans et al., 1977). In the present study, isolates were not tested for toxin production and it is difficult to speculate on the pathogenetic mechanism.

The present studies suggest that when a potentially pathogenic bacterium is to be incriminated as a cause of gastroenteritis, its demonstration in the jejunum may be an important criterion in establishing its pathogenicity. It is recommended that future studies on the aetiology of acute gastroenteritis in childhood should always include studies of jejunal flora.

\section{SUMMARY}

The microbial flora of the jejunal lumen of 28 infants with acute gastroenteritis was compared with that of a group of 10 normal infants. The jejunum of control subjects harboured an "oral "type of flora and in a few instances enterobacteria in small numbers. The concentrations of all but one of the groups of organisms were higher in the patients than in controls, and the differences were of statistical significance for enterobacteria and lactobacilli. In eight subjects, the same pathogen was identified in the jejunum and the stool. In six subjects with rotavirus infection, there were almost no Gramnegative aerobic rods in the jejunum. The possible role of other Gramnegative aerobic rods in producing gastroenteritis is discussed. It is suggested that studies of jejunal flora are of considerable importance in assigning an aetiological role to bacteria in the causation of acute gastroenteritis.

M. J. A. is in receipt of a Senior Research Fellowship from the Council of Scientific and Industrial Research, India.

\section{REFERENCES}

Bhat, P., Shantakumari, S., Rajan, D., Mathan, V. I., Kapadia, C. R., Swarnabai, C. AND BAKER, S. J. 1972. Bacterial flora of the gastro-intestinal tract in southern Indian control subjects and patients with tropical sprue. Gastroenterology, 62, 11.

Bishop, R. F., BARNES, G. L. AND TownLeY, R. R. W. 1974a. Microbial flora of stomach and small intestine in infantile gastroenteritis. Acta. paediat. scand., 63, 418. 
Bishop, R. F., Davidson, G. P., Holmes, I. H. AND Ruck, B. J. 1974b. Detection of a new virus by electron microscopy of faecal extracts from children with acute gastroenteritis. Lancet, $1,149$.

Challacombe, D. N., Richardson, J. M. ANd Anderson, C. M. 1974a. Bacterial microflora of the upper gastrointestinal tract in infants without diarrhea. Archs Dis. Childh., 49, 264.

Challacombe, D. N., Richardson, J. M., Rowe, B. and Anderson, C. M. 1974b. Bacterial microflora of the upper gastro-intestinal tract in infants with protracted diarrhea. Archs Dis. Childh., 49, 270.

Evans, D. J., JR, Evans, D. G., Dupont, H. L., ØRskov, F. AND ØRskov, I. 1977. Pattern of loss of enterotoxigenicity by Escherichia coli isolated from adults with diarrhea: suggestive evidence for an interrelationship with serotype. Infect. Immun., $17,105$.

Ferrao, V. AND MavinkURVE, S. 1977. Pseudomonas aeruginosa in infantile gastroenteritis. Arogya J. Hith Sci., 3, 85.

Flewett, T. H., BRyden, A. S. ANd Davies, H. 1974. Diagnostic electron microscopy of the faeces. 1. The viral flora of the faeces as seen by electronmicroscopy. J. clin. Path., 27, 603.

Flewett, T. H., Davies, H., Bryden, A. S. and Robertson, M. J. 1974. Diagnostic electronmicroscopy of faeces. II. Acute gastroenteritis associated with reovirus-like particles. J. clin. Path., 27, 608.

Gorbach, S. L., Banwell, J. G., Chatterjee, B. D., Jacobs, B. and Sack, R. B. 1971. Acute undifferentiated human diarrhea in the tropics. I. Alterations in intestinal microflora. J. clin. Invest., 50, 881.

Gorbach, S. L., Mahalanabis, D., Brayton, J., Jacobs, B., Chatterjee, B. D. and Neogy, K. N. 1970. Intestinal microflora in Asiatic cholera. III. Studies in pediatric cholera. J. Infect. Dis., 121, 46.

GoRDon, J. E. 1971 Diarrheal disease of early childhood-worldwide scope of the problem. Ann. N.Y. Acad. Sci., 176, 9.

Gross, R. J., Scotland, S. M. AND Rowe, B. 1976. Enterotoxin testing of Escherichia coli causing epidemic infantile enteritis in the U.K. Lancet, 1, 629.

Guerrant, R. L., Moore, R. A., Kirschenfield, P. M. ANd SAnde, M. A. 1975. Role of toxigenic and invasive bacteria in acute diarrhea of childhood. N. Engl. J. Med., 293, 567.

Henderson, A., Maclaurin, J. And Scott, J. M. 1969. Pseudomonas in a Glasgow baby unit. Lancet, 2, 316.

Klipstein, F. A., Holdeman, L. V., Corcino, J. J. and Moore, W. E. C. 1973. Enterotoxigenic intestinal bacteria in tropical sprue. Ann. intern. Med., 79, 632.

Koya, G., KosakaI, N. AND Fukasawa, Y. 1954. Supplementary studies on the multiplication of Escherichia coli 0111: B4 in the intestinal tract of adult volunteers and its relation to manifestation of colienteritis. Jap. J. med.Sci. Biol., 7, 655.

Middleton, P. J., Szymanski, M. T., Abbott, G. D., Bortolussi, R. and Hamllton, J. R. 1974. Orbivirus acute gastroenteritis of infancy. Lancet, $1,1241$.

Maiya, P. P., Pereira, S. M., Mathan, M., Bhat, P., Albert, M. J. and Baker, S. J. 1977. Etiology of acute gastroenteritis in infancy and early childhood in Southern India. Archs Dis. Childh., 52, 482.

Olarte, J., Ferguson, W. W., Henderson, N. D. And Torregrosa, I. 1961. Klebsiella strains isolated from diarrhoeal infants-human volunteer studies. Am.J. Dis. Childh., 101, 763.

Ørskov, F., Ørskov, I., Evans, D. J., JR, SACK, R. B., SACK, D. A. ANd WadSTrøm, T. 1976. Special Escherichia coli serotypes among enterotoxigenic strains from diarrhea in adults and children. Med. Microbiol. Immun., 162, 73.

Sack, R. B., Hirschhorn, N., Brownlee, I., CASh, R. A., WoOdWard, W. E. AND Sack, D. A. 1975. Enterotoxigenic Escherichia coli associated diarrheal disease in Apache children. N. Engl. J. Med., 292, 1041. 
Sakazaki, R., TAmura, K. ANd SaIto, M. 1967. Enteropathogenic Escherichia coli associated with diarrhoea in children and adults. Jap. J. med. Sci. Biol., 20, 387.

TномsоN, S. 1955. The role of certain varieties of Bacterium coli in gastroenteritis of babies. J. Hyg., Camb., 53, 357.

Wadstrom, T., Aust-Kettis, A., Habte, D., Holmgren, J., Meeuwisse, G., Mollby, R. AND SODERLIND, O. 1976. Enterotoxin-producing bacteria and parasites in stools of Ethiopian children with diarrheal disease. Archs Dis. Childh., 51, 865. 